\title{
Hvorfor Gladsaxemodellen fejlede - om anvendelse af algoritmer på socialt udsatte børn
}

\author{
Af Kenneth Kristensen *)
}

\begin{abstract}
Resumé
Anvendelse af algoritmer i velfærdsopgaver er nyt. Potentialet er stort, faldgruberne dybe. "Projekt dataunderstøttet tidlig opsporing af udsatte børn" i Gladsaxe Kommune havde stor interesse, men det blev som følge af mediestorm, aftagende opbakning fra landspolitikerne og hensyn til borgernes tillid lukket allerede i udviklingsfasen. Artiklen beskriver projektforløbet i Gladsaxe, analyserer udfaldet og identificerer en række opmærksomhedspunkter for en kommunal direktion ved anvendelse af algoritmer i velfærdsopgaver. Artiklen bidrager desuden til litteraturen om brugen af algoritmer med et fokus på direktionens rolle samt med et eksempel på anvendelsen af public valueteori på empiriske algoritmecases.
\end{abstract}

Emneord: Topledelse, kommuner, algoritmer, digitalisering, udsatte børn 


\section{A. Kan man anvende algoritmer på udsatte børn?}

\section{Baggrund}

I foråret 2018 udbrød en debat i landsdækkende dagblade, på sociale medier mv., hvor et projekt i Gladsaxe Kommune blev sammenlignet med overvågningsmetoder fra George Orwells "1984”, DDR og Kina. Anledningen var en frikommuneansøgning, hvor Gladsaxe Kommune søgte om mulighed for at udvikle en algoritmebaseret opsporingsmodel med det formål "at hjælpe børn, i risiko for at blive udsat, tidligst muligt" (Gladsaxe Kommune, 2017: 3). Dvs. tidlig forebyggelse gennem mønstergenkendelse, der både i kompleksitet og intimitet gik længere end f.eks. en database. Anvendelsen af algoritmer var en helt ny tilgang til forebyggelse af sager om mistrivsel og overgreb på børn, som sager fra Tønder, Rebild og Brønderslev havde sat højt på kommunernes og mediernes dagsordener. Projektideen i Gladsaxe gav håb om, at der var en vej til at forebygge sådanne sager, men som følge af mediekritikken, aftagende landspolitisk opbakning til at skabe det nødvendige juridiske grundlag samt hensyn til borgernes tillid til kommunen, så blev projekt dataunderstøttet tidlig opsporing (DTO) skrinlagt i udviklingsfasen primo 2019.

Gladsaxe Kommune er en mellemstor kommune med ca. 70.000 indbyggere og et relativt højt indtægtsgrundlag, hvilket giver volumen og organisatoriske ressourcer over landsgennemsnittet. Gladsaxe har et stabilt politisk styre med socialdemokratiske borgmestre i mere end hundrede år. En evaluering fra VIVE/Oxford Research viste meget fine resultater fra en af Gladsaxe Kommunes analoge, forebyggende og tværgående indsatser på familieområdet 2016-2019 (Hjelmar et al., 2020), hvilket indikerer en solid faglighed på familieområdet. Gladsaxe kunne altså umiddelbart se ud til at have både den fornødne politiske stabilitet, økonomiske ressourcer og faglige kompetencer til at gennemføre projekt DTO. Så hvorfor lykkedes det ikke?

\section{Afgrænsning}

Inden for digitaliseringslitteraturen diskuteres forskellige definitioner, kategorier og anvendelser af blandt andet big data, automatisering, algoritmer, maskinlæring og kunstig intelligens (Mittelstadt et al., 2016; Bach, Svejgaard og Hjorth, 2019; Mergel, Rethemeyer og Isett, 2016; Wirtz, Weyerer og Geyer, 2019). Denne artikel vil ikke forfølge dette spor yderligere, fordi aktørerne i debatten om projekt DTO tog afsæt i en lægmandsforståelse af algoritmebegrebet. En algoritme er ifølge Cambridge-ordbogens definition: "A set of mathematical instructions or rules that, especially if given to a computer, will help to calculate an answer to a problem". Algoritmer er blot en af mange teknologier i digitaliseringen af den offentlige sektor, beskrevet som "the adaptation of the public sector to completely embrace and imbed electronical delivery at the heart of the government business model, whenever possible" (Margetts og Dunleavy, 2013: 6). Samme forfattere ser i paradigmet "Digital Era Governance" digitalisering som en drivkraft, der gennemgribende forandrer offentlige strukturer til at være mere helheds- og borgerorienterede (Dunleavy et al., 2006). 
Bovens og Zouridis beskriver, hvordan digitale teknologier gradvist overtager skønsvurderingen fra frontmedarbejderne, og teknologiernes funktion ændrer sig fra at registrere data til at fastlægge proceduren for vurdering, "screen-level bureaucracy", og til sidst semi- eller fuldautomatisk at udøve selve skønsvurderingen, "system-level bureaucracy" (Bovens og Zouridis, 2002). En del studier videreudvikler denne pointe (fx Wihlborg, Larsson og Hedström, 2016; Busch, Henriksen og Sæbø, 2018; Bullock, 2019). Andre studier har fokus på den etiske dimension i forhold til borgerne (Winthereik, 2020), jura og transparens (fx Sørensen, 2018; Olsen et al., 2019; Andersen og Motzfeldt, 2019), fagpersoners involvering (Holten Møller, Shklovski og Hildebrandt, 2020), værdier (Røhl, 2020), digital transformationsledelse (Nielsen, Elmholdt og Noesgaard, 2020) eller beslutningsstøttesystemer (Gillingham, 2019). Om skepsis i forhold til algoritmer introducerer Dietvorst et al. begrebet algoritmeaversion (Dietvorst, Simmons og Massey, 2015), og Van Dalen viser, at der er forskel på accepten af algoritmers anvendelse på forskellige emner (Van Dalen, 2020). Hovedparten af disse studier har fokus på frontmedarbejdere eller mellemledere, mens direktionen er underbelyst. I denne artikel er det netop direktionens perspektiv, som er i fokus.

\section{Formål}

Gladsaxeforløbet anvendes som en case på de problemstillinger, som i et topledelsesperspektiv kan opstå ved anvendelse af algoritmer i velfærdsopgaver. Gladsaxe er valgt som case af to grunde. For det første, fordi projekt DTO, kendt som "Gladsaxemodellen", var blandt de første algoritmeprojekter i danske kommuner og siden er blevet et markant referencepunkt i den offentlige debat. For det andet, fordi "udsatte børn" er et meget følsomt emne for alle aktører (Bjørn, 2020), ikke mindst når emnet kombineres med anvendelsen af algoritmer (Van Dalen, 2020). Projekt DTO var således både teknologisk og emnemæssigt et mere vidtgående projekt end hidtil set i danske kommuner. Dermed kan projektet betegnes som en "ekstrem" case, der ikke er repræsentativ, men til gengæld særligt rig på information om de dybere årsager i problematiske cases, fordi de aktiverer flere aktører og basale mekanismer i den studerede situation (Flyvbjerg, 2006). Erfaringerne fra Gladsaxe er derfor relevante for andre kommuner, der i disse år står foran strategiske valg om anvendelsen af algoritmer $i$ alt fra jobformidling til genoptræning. Potentialet $i$ algoritmer for mere effektiv, målrettet og fleksibel borgerservice er stort, men omvendt kan algoritmeprojekter også medføre f.eks. bias, uigennemsigtige beslutninger, brud på retsprincipper og tab af privatliv og borgernes tillid til det offentlige (fx Sweeney, 2000; Andrews, 2019; KL, 2019; Regeringen, 2019). Dermed er projekt DTO også velegnet til at besvare forskningsspørgsmålet: Hvorfor blev udfaldet af projekt DTO en projektafbrydelse? - og hvilke opmoerksomhedspunkter for en kommunal direktion kan identificeres ved anvendelse af algoritmer i velfordsopgaver?

\section{Disposition}

I besvarelsen af ovenstående beskrives først to teoretiske perspektiver på direktionens rolle. Derefter fremlægges artiklens metode samt det empiriske forløb i casen indhentet ved 
dokumentanalyse og interviews med nøgleaktører i Gladsaxe Kommune. I analysen anvendes den præsenterede litteratur til at forklare udfaldet af projekt DTO og siden at identificere opmærksomhedspunkter for en kommunal direktion ved anvendelse af algoritmer. Afslutningsvist drøftes artiklens begrænsninger og nøglespørgsmål til yderligere undersøgelse.

\section{B. Direktionens ledelsesrolle}

\section{Teorivalg}

Til at belyse direktionens ledelsesrolle er i denne artikel valgt et traditionelt offentligt administrationsperspektiv (TOA), fordi det beskriver direktionens klassiske ledelsesrolle i styringskæden opad til det politiske niveau og nedad til den øvrige forvaltning. Dermed beskriver TOA den forventede arbejdsdeling mellem politikere og forvaltning i en kommune. Desuden er valgt et public value management (PVM)-perspektiv, fordi det tilbyder et supplerende og mere praksisnært perspektiv, der beskriver direktionen som entreprenør og opdagelsesrejsende i forhold til at finde løsninger på komplekse samfundsproblemer (Moore, 1995). Tilsammen udgør TOA og PVM undersøgelsens analyseramme.

\section{Traditionel offentlig administration (TOA)}

TOA bygger på Webers bureaukratimodel (Weber, 1922 [Fivelsdal 1971]; Stoker, 2006). Med afsæt heri samt den parlamentariske styringskæde (Olsen, 1978) kan opstilles en hierarkisk og idealiseret kommunal styringskæde, som blandt andet udtrykker forventningen til direktionens ledelsesrolle. I denne styringskæde vælger borgerne i en kommune et byråd, som delegeres beslutningskompetencen for de kommunale opgaver. Byrådet ansætter direktionen, der delegeres beslutningskompetence til at gennemføre de politiske beslutninger. Direktionen ansætter fagpersoner i forvaltningen, som delegeres udførelsen af opgaverne. I den "modsatte retning" står hvert led i styringskæden til ansvar for det foregående led, som forventer feedback, dvs. at fagpersoner i forvaltningen informerer direktionen, der orienterer politikerne om resultater og faglighed. På den baggrund fører politikerne dialog med borgerne om kommunens udfordringer og løsninger (KL og Økonomi- og Indenrigsministeriet, 2017). I den idealiserede rollefordeling fastlægger politikerne mål og rammer, mens direktionen konkretiserer de politiske mål og udøver styring og ledelse af forvaltningen for at realisere disse (Smith-Udvalget, 2015; Andersen et al., 2019). I et TOA-perspektiv er forventningen til den konkrete case fra Gladsaxe derfor én sammenhængende styringskæde, hvor byrådet har udstukket mål og rammer for arbejdet med socialt udsatte børn, hvor direktion og forvaltning har valgt at anvende algoritmer som supplement til analoge metoder, og hvor direktionen har oplyst byrådet om metodevalget, så byrådet eventuelt kan korrigere samt føre dialog med borgere, presse mv. 
Den klare adskillelse i Webers bureaukratimodel mellem politik og administration har været udfordret af mange (fx Aberbach, Putnam og Rockman, 1981; Svara, 1999), hvilket er særligt relevant i relation til danske kommuner, hvor rollefordelingen i praksis er mere uklar, og politikerne også tager del i gennemførelsen af de politiske beslutninger (Andersen et al., 2019). Tilsvarende betyder en professionaliseret direktion, at direktionen påvirker og indgår i politikudvikling (Lê Madsen og Kjær, 2015; Bertelsen og Hansen, 2016; Blom-Hansen, Baekgaard og Serritzlew, 2020). I praksis er det derfor også centrale roller for en direktion at agere strategisk udviklingskraft og brobygger mellem politikerne og fagpersonerne i forvaltningen.

\section{Public Value Management (PVM)}

I tråd med den overlappende rollefordeling mellem politik og forvaltning formulerer PVM en større og mere proaktiv rolle til den offentlige leder, hvor ledelsesopgaven blandt andet består i at udvikle tiltag, engagere borgere og skabe værdi for borgere og samfund (Moore, 1995; Stoker, 2006; Jørgensen og Bozeman, 2007). Moore beskriver i sin "strategiske trekant" (Moore, 1995; Moore og Khagram, 2004), hvordan den offentlige leder må: 1) afstemme forståelsen af offentlig værdi med interessenterne. I fraværet af en objektiv standard for succesfulde resultater i den offentlige sektor må lederen balancere mellem forskellige interessenters ønskede mål og effekter af den offentlige aktivitet, f.eks. brugertilfredshed eller brede samfundsværdier som åbenhed og integritet. Interessenterne omfatter derfor ikke bare de direkte brugere af services, men også øvrige samfundsborgere og interessegrupper. 2) Sikre legitimitet og opbakning i den demokratiske debat mellem politikere og andre samfundsaktører. Det er ikke tilstrækkeligt, at offentlige ledere selv fastsætter værdi og mål for deres aktiviteter, da der er brug for legitimitet og støtte hertil fra de "autoritative omgivelser", hvilket vil sige de folkevalgte politikere, og de, som påvirker byrådet. 3) Operationel kapacitet til at gennemføre værdiskabende aktiviteter, hvilket kan være interne ressourcer og kompetencer i organisationen, men også eksterne bidrag fra f.eks. familier. Anvendt på Gladsaxecasen vil det således være en forudsætning, at der identificeres offentlig værdi for de berørte familier og samfundet $i$ at anvende algoritmer, at metoden legitimeres af byrådet og bakkes op af dem, som påvirker byrådet, og at kommunen har ressourcer, kompetencer, data og lovgivningsmæssige rammer til at bruge algoritmen.

PVM er blandt andet blevet kritiseret for at være en diffus teori, der marginaliserer politikere og har for stor tiltro til offentligere lederes rolle som neutrale fortolkere og "platoniske beskyttere" af offentlig værdi (Rhodes og Wanna, 2007; Turkel og Turkel, 2016). Ikke desto mindre har PVM opnået stor popularitet især hos praktikere (Andersen et al., 2020), blandt andet fordi Moore's strategiske trekant tilbyder en enkel analysemodel i forhold til offentlige lederes behov for at lede opad, udad og nedad (Bryson et al., 2017). Andrews bekræfter anvendeligheden af Moores strategiske trekant til at forstå, hvordan regeringer tilgår nye og komplekse emner som anvendelse af algoritmer. I en række cases viser Andrews, hvordan f.eks. racemæssig bias i anvendelse af algoritmer udfordrer 
offentlige værdier. Han noterer behovet for opbakning til regulering af anvendelsen af algoritmer, og han påpeger den begrænsede operationelle kapacitet til at gennemføre reguleringen (Andrews, 2019).

\section{Metode}

\section{Dataindsamling}

Undersøgelsen anvender kvalitative datakilder til at kortlægge forløbet omkring projekt DTO og til at identificere afgørende faktorer for projektets afbrydelse. Datakilderne er primært dokumenter fra Gladsaxe Kommune, workshops og interviews med kommunens nøgleaktører. Der er således valgt et "indefra-perspektiv", hvilket giver stor indsigt i de faktuelle forhold og nøgleaktørernes overvejelser om forløbet. Risikoen ved denne tilgang kan naturligvis være bias i respondenternes vurdering af egen ageren. Kritisk opmærksomhed på dette forhold indgår i analysen, og der er ved triangulering tilstræbt at have forskellige kilder på beskrivelser og vurderinger. Dataindsamling og -analyse blev gennemført i perioden august-december 2020.

For at kortlægge de faktuelle forhold og skabe grundlag for kritisk vurdering af respondenternes udsagn anviste forfatteren typer af skriftligt materiale, som Gladsaxe Kommune fremfandt. På baggrund af det tilsendte materiale blev yderligere materiale ønsket og fremfundet. Vedrørende selve projekt DTO bestod materialet af projektbeskrivelse, interne notater, ansøgninger, ekstern korrespondance, beskrivelser af foreløbig datamodel samt dagsordener og referater fra styregruppemøder, politiske møder mv. Andre relevante dokumenter omfattede strategier, evalueringer og rapporter om Gladsaxe Kommunes arbejde på familieområdet samt datadrevet forretningsudvikling og datasikkerhed. Desuden fremfandt forfatteren via Infomedia.dk artikler om Gladsaxeforløbet i dag- og fagblade fra perioden 2018-2020 ved søgeord som "Gladsaxe", "digitalisering", "algoritme", "data", "datalæk", "børn" mv. Forfatterens udkast til beskrivelse af indhold og tidsforløb af projekt DTO blev forelagt projektledere mv. i forvaltningen på to workshops med henblik på validering og kvalificering af faktuelle forhold.

Med input fra et eksternt sparringspanel bestående af en kommunaldirektør og en regionsdirektør blev udarbejdet en interviewguide. For at indhente vurderinger fra forskellige vinkler blev gennemført i alt 13 interviews med nøgleaktører i projektforløbet på forskellige niveauer af organisationen fordelt på tre grupper: Politikere, direktion og fagpersoner. De fire politikere omfattede borgmester samt udvalgsformand og to medlemmer af Børne- og Undervisningsudvalget. De fire politikere var udvalgt fra fire forskellige parter (A, B, C, Ø) med forventning om derved at opnå bredde og variation i vurderingerne. Desuden indgik fire direktionsmedlemmer og fem fagpersoner fra familie-, IT- og dataområderne i interviewrunden. 
Som følge af Covid 19-restriktioner blev alle interviews gennemført som videomøder. Varigheden af hvert interview var mellem 23 og 44 minutter. Alle interviews blev gennemført som individuelle interviews for at minimere bias for magtrelationer og tendens til konsensus i gruppeinterviews (Fontana og Frey, 1994). Alle interviews var semistrukturerede omkring hovedtemaerne projektforløb, nøgleproblemstillinger, tilgange og opmærksomhedspunkter. Der blev stillet åbne spørgsmål, hvor respondenterne havde lejlighed til at udpege og beskrive problemstillinger.

\section{Dataanalyse}

Interviewene blev analyseret med anvendelse af Miles og Huberman-modellen til kvalitativ analyse (Miles og Huberman, 1994) og software-værktøjet NVivo 1.5.1. Modellen anviser en systematisk, interaktiv og iterativ proces mellem dataindsamling, datareduktion, datadisplay og konklusioner. De transskriberede interviews blev i en empiridrevet, åben og deskriptiv kodeproces, uden fortolkning, reduceret til ca. 300 kodningsenheder segmenteret i kortere udsagn på få linjer. Hensigten var at "lade data tale" og således at få indsigt i de involverede nøgleaktørers egne refleksioner over problemstillinger i projekt DTO. Heraf opstod en 1. runde kodeliste, hvor de 300 kodningsenheder blev fordelt på 16 temaer/koder med udspring i interviewene. Udsagnene blev herefter mønsterkodet ved en indholdsmæssig fortolkning af sammenhænge, clustering. Fortolkningen blev dels støttet af forfatterens egne notater, nedskrevet umiddelbart efter interviewene, dels af det skriftlige materiale om projekt DTO. Foreløbige "konklusioner" blev opsamlet i et datadisplay fordelt på de tre respondentgrupper.

\begin{tabular}{|l|l|}
\hline Citater fra respondenter & $\begin{array}{l}\text { Foreløbig } \\
\text { konklusion }\end{array}$ \\
\hline "Jeg tror slet ikke, at vi havde regnet med der ville vaere sådan en shitstorm & $\begin{array}{l}\text { Mediekritik } \\
\text { omkring det." (Fagperson 1). }\end{array}$ \\
"Et vigtigt loeringspunkt, er jo nok i virkeligheden ... altså det kom bag på \\
os i den grad, at der kom den omtale." (Fagperson 2) \\
"Skulle vi få lov at lancere det her igen, eller skulle vi gøre noget andet, der \\
havde sådan en kontroversiel karakter, så ville jeg godt nok lige saette mig \\
ned og toenke godt og grundigt over, hvad er det for en kontakt, vi skal have \\
med pressen? Hvordan skal vi have det her lanceret? Hvordan vil vi \\
kommunikere det?" (Fagperson 3). \\
"Jeg toenker det kom bag på alle, hvor meget bevågenhed det fik det her." \\
(Fagperson 4). & \\
& \\
\hline
\end{tabular}

Tabel 1. Fra citater til foreløbig konklusion - et eksempel. 
I en iterativ proces mellem kodning, datadisplay og foreløbige konklusioner blev antallet af temaer reduceret fra 16 til 9 temaer i en slutkodning. Konklusionerne blev til sidst forelagt respondenterne fra direktion og fagpersoner til kommentering og validering.

I artiklens analyseafsnit sammenholdes den teoretiske analyseramme med empirien fra dels beskrivelsen af tidsforløbet af projekt DTO og dels konklusioner fra interviewene. Tabel 2 viser, hvilke af slutkoderne som indgår i analysens forskellige elementer.

\begin{tabular}{|c|c|}
\hline Slutkoder & Analyseramme \\
\hline $\begin{array}{l}\text { 1. Politikernes rolle - om politikernes } \\
\text { opgaver og adfærd } \\
\text { 2. Kommunikation - om ekstern } \\
\text { kommunikation med medier, aktører } \\
\text { mv. } \\
\text { 3. Proces - om processer, tempo mv. } \\
\text { 4. Jura - om jura og rettigheder } \\
\text { 5. Data - om data, -adgang, -kvalitet mv. } \\
\text { 6. Etik og tillid - om etik, borgernes tillid } \\
\text { mv } \\
\text { 7. Organisation og kompetencer - om } \\
\text { intern struktur, kultur, aktører, ledelse, } \\
\text { kompetencer mv. } \\
\text { 8. Direktionens rolle - om direktionens } \\
\text { opgaver og adfærd } \\
\text { 9. Teknologi - om opfattelser af teknologi. }\end{array}$ & $\begin{array}{l}\text { - } \quad \text { Styringskæde (Slutkode } 1+2 \text { ) } \\
\text { - } \quad \text { Legitimering og opbakning (slutkode } 2+3 \text { ) } \\
\text { - } \quad \text { Offentlig værdi (Slutkode } 3+4+5+6 \text { ) } \\
\text { - } \quad \text { Operationel kapacitet (Slutkode } 7+8 \text { ) }\end{array}$ \\
\hline
\end{tabular}

Tabel 2. Interviews: Fra kodning til anvendelse i analyse

\section{Tidsforløbet i projekt DTO}

Projekt DTO’s tidsforløb kan opdeles i fire delvist overlappende faser.

\section{Forhistorie og idé. Juni 2016-februar 2018.}

En ny direktør for børn og kultur med erfaring og nysgerrighed på datadrevet ledelse blev ansat $\mathrm{i}$ februar 2016. Desuden konstaterede familieafdelingen i samarbejde med blandt andet social- og beskæftigelsesområderne i foråret 2016, at børn med mistrivsel ofte først blev identificeret i 8-12års alderen, selv om en sagsgennemgang viste, at forskellige afdelinger i kommunen hver især havde konstateret tegn på mistrivsel tidligere. Dvs. at forvaltningen blev opmærksom på, at man ikke i tilstrækkelig grad havde "forbundet punkterne til et samlet billede". Med denne viden, og med 
henvisninger til nyere forskning om udsatte børn, blev en sag forelagt Børne- og Undervisningsudvalget, der i juni 2016 godkendte strategien "Strategi for tidlig indsats - Familier der lykkes". Strategien fokuserede på tidlig opsporing af socialt udsatte børn og familier på tværs af fagligheder (Gladsaxe Kommune, 2016).

Gladsaxe Kommune blev udpeget af Økonomi- og Indenrigsministeriet som frikommune i oktober 2016, hvilket åbnede mulighed for dispensation fra gældende lovgivning. Desuden var der et ønske i Gladsaxe Kommunes direktion om at arbejde tværgående, forebyggende og dataunderstøttet. Det blev derfor besluttet i direktionen at etablere en enhed, Datadrevet Forretningsudvikling (DAFO), fra oktober 2017. DAFO-enheden bestod af få faste medarbejdere samt repræsentanter fra andre afdelinger et par dage om ugen. En tværgående DAFO-styregruppe med børne- og kulturdirektøren som formand traf beslutninger om enhedens projekter.

Da strategien "Familier der lykkes" skulle udmøntes i konkrete projekter, var det nærliggende, at der foruden et antal analoge projekter, f.eks. "Opsporing i dagtilbud" og "Familiesupporten", også blev formuleret et projekt om dataunderstøttet tidlig opsporing. Der blev nedsat en arbejdsgruppe, der i foråret 2017 gennemførte den indledende vurdering af jura, datatilgængelighed, datamodel samt forhåndsdialog med Økonomi- og Indenrigsministeriet. Udkast til ansøgning om frikommuneprojekt blev godkendt af Økonomiudvalget og siden Byrådet i september 2017 med 24 stemmer for og 1 stemme imod. Projektet blev forelagt tre politiske fagudvalg til efterretning i november 2017. I projektansøgningen blev søgt om dispensation til at samkøre en liste af data på tværs af forskellige forvaltningsområder, og en foreløbig opsporingsproces blev beskrevet.

I december 2017 gav Økonomi- og Indenrigsministeriet afslag på frikommuneansøgning om projekt DTO, men tilkendegav samtidig, at ansøgningen ville søges imødekommet i en generel lovadgang med udgangspunkt i databeskyttelsesloven (L 502), som var under behandling som lovforslag i Folketinget. Efterfølgende henviste Regeringen direkte til inspiration fra Gladsaxes frikommuneansøgning i regeringens "ghettoudspil" 1. marts 2018 (Regeringen, 2018).

\section{Mediestorm. Marts 2018.}

Regeringens ghettoudspil førte til stor mediemæssig interesse for Gladsaxes DTO-projekt startende med en Ritzau-nyhed 27. februar 2018 (Ritzau Fokus, 2018) og en artikel 3. marts i Politiken "Regeringen vil overvåge alle landets børnefamilier og uddele point" (Sorgenfri Kjær, 2018c). Derfra fulgte en større debat i nationale medier og på sociale medier (fx Gjerding, 2018; Jensen og Østergaard, 2018). De fleste debattører var kritiske overfor overvågning, manglende transparens, risiko for datamisbrug og borgernes rettigheder. Dvs. kritikken gik på Gladsaxes ønske om at anvende en algoritme og ikke det at opspore socialt udsatte børn tidligere. En undtagelse var dog tidligere formand for Børnerådet, Lisbeth Zornig Andersen, der i en artikel blev citeret for, at man 
snarere burde gå endnu længere i anvendelsen af data (Lessel og Houlind, 2018). Debatten forholdt sig også til Regeringens ghettoudspil og den reviderede databeskyttelseslov, og Gladsaxe Kommunes projekt blev således uforvarende en del af den nationale debat om integration og privatliv. I Gladsaxe Kommune førte kritikken til, at byrådet blev orienteret af forvaltningen om status på projekt DTO på et byrådsseminar i marts 2018 samt i en opfølgende mail. Mediekritikken gav anledning til politisk bekymring og spørgsmål, men der blev ikke politisk fremsat ønske om at stoppe projekt DTO, yderligere redegørelser eller drøftelser i politiske udvalg.

\section{Modelarbejde. Januar-november 2018.}

Hverken nationalt eller lokalpolitisk var der beslutninger, der stoppede projekt DTO efter mediekritikken. Derfor fortsatte modelarbejdet internt i Gladsaxe Kommune. Hverken datamodellen eller de procesmæssige dele blev færdigudviklet og operationaliseret, men grundelementerne var: 1) På baggrund af et litteraturstudie, gennemgang af ti borgersager samt input fra fagmedarbejdere blev der udpeget 44 potentielle risikoindikatorer for mistrivsel hos 0-6-årige børn, f.eks. støtte fra Pædagogisk Psykologisk Rådgivning. 2) Samkørsel af risikoindikatorerne i en datamodel, der skulle trænes på data fra alle børn i Gladsaxe Kommune i alderen 0-6 år opdelt i to grupper - udsatte børn / kontrolgruppe af øvrige børn. 3) Datamodellen var ikke et pointsystem, som fremført i medierne, men en algoritme, der skulle beregne hvilke risikoindikatorer, og hvilken kombination af indikatorer, der gav størst statistisk signifikans for korrelation til "udsathed". Datamodellen skulle anvende metoden "prædiktivt beslutningstræ", fordi metoden gav stor gennemsigtighed i mellemregningerne. Datamodellen kunne anvendes til at beregne "risiko for udsathed" udtrykt som procentsatser for forskellige grupperinger af børn. 4) Fagmedarbejdere skulle foretage indledende vurdering af data. På denne baggrund kunne fagmedarbejderen forkaste og slette sagen eller kontakte familien for samtykke til egentlig sagsbehandling, der kunne føre til evt. tilbud om hjælp. Hvis familien ikke ønskede at give samtykke, så skulle sagen slettes. Grundlæggende var tanken at tilbyde et "samarbejde i øjenhøjde" med de identificerede potentielt udsatte familier. Samarbejde med faglige organisationer og Danmarks Statistik blev afsøgt for at kvalificere processen og modellen. Modelarbejdet viste, at dataadgang, -kvalitet og -historik var en udfordring.

På trods af Regeringens oprindelige intention åbnede vedtagelsen af Databeskyttelsesloven i maj 2018 ikke mulighed for at imødekomme Gladsaxe Kommunes frikommuneansøgning om projekt DTO. Til gengæld åbnede et nyt lovforslag (Lov 707) om "en helhedsorienteret plan" fra 8. juni 2018 samt daværende børne- og socialminister Mai Mercados støtte til projekt DTO på et åbent samråd 21. juni 2018 nye forhåbninger i Gladsaxe. I august besøgte repræsentanter fra Børne- og Socialministeriet Gladsaxe Kommune, og der blev indledt dialog med ministeriet om mulighederne for at kunne gennemføre (dele af) projekt DTO. Gladsaxe Kommunes fagudvalg blev i november 2018 orienteret om status på projekt DTO. 


\section{Datalæk og nedlukning. December 2018-april 2019.}

Fra efteråret 2018 blev projekt DTO nedprioriteret af forvaltningen til fordel for de analoge projekter under "Familier der lykkes". Det var dog et datalæk uden direkte forbindelse til projekt DTO, der udløste lukning af projektet. Den 3. december 2018 blev fire PC'er stjålet fra rådhuset, hvoraf den ene indeholdt et regneark med fortrolige personoplysninger, herunder ca. 20.000 CPRnumre. Datalækket blev anmeldt til Datatilsynet, og byråd og berørte borgere orienteret, men tilliden til kommunen havde lidt skade. I medierne kom der fornyet kritik af Gladsaxe Kommune (Mchangama og Liu, 2018) og en sammenkædning med projekt DTO (f.eks. Sorgenfri Kjær, 2018a). På den baggrund trak Christina Egelund fra et af de daværende regeringspartier, Liberal Alliance, 14. december 2018 støtten til projekt DTO (Sorgenfri Kjær, 2018b). Dermed var Folketingets opbakning til projekt DTO væk, og forvaltningen besluttede på et styregruppemøde for DAFO i januar 2019 at sætte projektet i bero. På et møde 5. februar 2019 besluttede et enigt Økonomiudvalg at iværksætte en ekstern gennemgang af informationssikkerheden i Gladsaxe Kommune, og på Økonomiudvalgets møde 30. april 2019 fremlagde konsulentfirmaet PWC sin rapport og forvaltningen sine anbefalinger. På denne baggrund besluttede et enigt Økonomiudvalg at afsætte yderligere syv årsværk til informationssikkerhed samt behov for yderligere teknologianskaffelser.

\section{E. Hvorfor blev projektet i Gladsaxe afbrudt?}

Udfaldet af Gladsaxecasen analyseres med anvendelse af analyserammen bestående af styringskæden fra TOA-perspektivet og Moores strategiske trekant fra PVM-perspektivet samt det beskrevne tidsforløb og respondenternes forklaringer.

\section{Styringskæden}

Tidsforløbet viser, at forvaltningen udviklede projekt DTO som én blandt flere indsatser, der skulle udmønte de politiske mål fastlagt i strategien "Familier der lykkes", og at projekt DTO blev godkendt politisk i forbindelse med frikommuneansøgningen. Dermed var den politiske rygdækning på plads, og den begrænsede politiske involvering i projektet var i tråd med den forventede arbejdsdeling mellem politikere og forvaltning i styringskæden. Set i bakspejlet er både politiske og administrative respondenter dog enige om, at det ville have været en fordel med politikerne tidligere og tættere inde over projekt DTO’s formål, kriterier, risici og metode, fordi dette projekt havde til hensigt at anvende nye, digitale og kontroversielle tilgange til borgerne.

”... i et eller andet omfang, så kan vi jo godt lide at være med på rejsen, og jeg tænker også, at det bliver mere kvalificeret af, at vi kommer med ind sådan ret tidligt i loopet. På det rigtige niveau - altså på det politiske niveau og ikke på det tekniske.” (Borgmester). 
De interviewede politikere fremhæver også, at de ved godkendelsen af frikommuneansøgningen var fokuseret på formålet med projektet, men ikke helt kunne overskue indholdet og konsekvenserne af de nye digitale metoder. Der opstod derfor ikke den nødvendige brobygning i styringskæden mellem på den ene side forvaltning og direktører og på den anden side det politiske liv i Gladsaxe.

"Vi bliver simpelthen nødt til at forklare politikerne, og det omfatter også mig selv, hvad er det her egentlig for noget? Altså hvad er kunstig intelligens for noget? Hvad er det for nogle udfordringer der ligger i det? Men sådan lidt basalt forstå, hvordan fungerer det? Hvad er det egentlig det gør?" (Formand for Børne- og Undervisningsudvalget).

Politikernes svage indsigt i projekt DTO viste sig at blive et problem i forbindelse med mediekritikken, hvor flere politikere i interviewene giver udtryk for, at de ikke følte sig tilstrækkeligt klædt på til at involvere sig i debatten. Dvs. at politikerne ikke var i stand til at forklare og forsvare projekt DTO, da mediekritikken brød ud. I et styringsperspektiv kan det argumenteres, at to af leddene i styringskæden løsnede sig, så der ikke var den fornødne kobling mellem hverken direktion og politikere eller mellem politikere og borgere.

\section{Legitimering og opbakning}

Den lokalpolitiske legitimering af projekt DTO er beskrevet ovenfor, men i et PVM-perspektiv har det også betydning at søge bred opbakning hos landspolitikere, interessenter, borgere mv. (Bryson et al., 2017). Tidsforløbet i projekt DTO viser, at der fra regeringens side var eksplicit opbakning til projektet frem til efteråret 2018, hvilket var stærkt medvirkende til, at Gladsaxe fortsatte projektudviklingen. Til gengæld var det først sent i forløbet, at de faglige organisationer blev inddraget, og borgerne blev det slet ikke. Flere af de interviewede fagpersoner og direktører giver udtryk for, at de anså projekt DTO som mere en ide end et færdigt projekt.

"I forhold til involvering af borgere i forhold til modellen, så nåede vi slet ikke langt nok i udviklingsarbejdet med modellen til, at det var aktuelt. Vores model ændrede sig undervejs i processen, og vi var ikke klar til at præsentere den offentligt.” (Børne- og kulturdirektør).

Af samme årsag erkendes det, at medieinteressen blev undervurderet. Fraværet af en proaktiv kommunikation om projektet var medvirkende til, at der i medierne opstod en række misforståelser og bekymringer, f.eks. at der var tale om en pointmodel, og at kommunen ville registrere "scoren" for hver familie i kommunen. Disse misforståelser blev gentaget i andre medier, rapporter mv. Desuden fokuserede mediehistorierne på de risici, som anvendelse af algoritmer kunne frygtes at indebære, og ikke på problemet med at finde uidentificerede børn på vej til alvorlig mistrivsel. Da mediekritikken brød ud, var der en vis offentlig opbakning fra børne- og socialministeren, men regeringen blev presset af medier og i Folketinget på temaer som transparens og overvågning som 
følge af det tidsmæssige sammenfald med ghettoudspil og vedtagelse af databeskyttelsesloven. Det blev således problematisk for projekt DTO, at der hverken var etableret alliancer med andre interessenter eller en understøttende kommunikation om problemet eller algoritmens anvendelse. I et PVM-perspektiv er pointen, at selv regeringens opbakning viste sig utilstrækkelig, fordi der ikke var en bredere legitimering og opbakning fra andre interessenter, borgere og medier til projekt DTO. Dermed var den første af forudsætningerne i Moores strategiske trekant ikke opfyldt.

\section{Offentlig værdi}

Mediekritikken viste tydeligt, at der var konfliktende opfattelser af offentlig værdi i projekt DTO. I administrationen havde man identificeret stor offentlig værdi i projekt DTO i form af bedre livskvalitet for udsatte børn, men eksterne aktører tillagde risici for overvågning, manglende transparens og datalæk større betydning end formålet. Selv om forvaltningen internt havde øje for disse problemstillinger, så blev de forskellige opfattelser af offentlig værdi ikke balanceret med interessenterne, og dermed fik man ikke eksplicit drøftet emner som åbenhed, rettigheder og integritet, der er blandt de grundlæggende samfundsværdier i PVM-perspektivet (Jørgensen og Bozeman, 2007). Flere af de interviewede politikere i Gladsaxe peger i den forbindelse på tilliden til kommunen som afgørende.

"Der er noget med, at de personer, som jo egentlig er dem, der skal hjælpe familierne, også bliver nogle, der skal rapportere. Det bliver tydeligt her. Sådan har det måske altid været. Fagmedarbejderne har vel altid vendt tilbage, hvis de havde bekymring, men at de bliver nogle personer, der direkte skal registrere data om folk. Det er faktisk ret bekymrende, fordi det kan få nogle familier til at fravælge besøg af sundhedsplejersken, hvis de er bange for, at de måske vil blive sat i en eller anden kategori." (Byrådsmedlem).

Trods disse bekymringer giver de involverede direktører samt fagpersoner i interviewene udtryk for, at de samtidig oplevede en etisk forpligtelse til at anvende de data, som kommunen lå inde med til at identificere potentielt udsatte børn i alvorlig mistrivsel, der ellers risikerede at blive overset. Den daværende kommunaldirektør har blandt andet i en debat på Folkemødet 2019 betegnet denne forpligtelse som "den dobbelte etik", hvor der ikke bare er etiske spørgsmål forbundet med at anvende kommunens data om borgerne, men jo også ved ikke at gøre det. Ikke desto mindre blev projekt DTO lukket, og fokus i stedet rettet mod at genskabe borgernes tillid gennem åbenhed om kommunens data samt store investeringer i datasikkerhed. Dvs. at få genskabt balancen i opfattelserne af offentlig værdi og dermed opfylde den anden forudsætning i Moores strategiske trekant. 


\section{Operationel kapacitet}

På baggrund af gode erfaringer fra analoge familieindsatser havde respondenterne stor tiltro til, at kommunens socialfaglige medarbejdere kunne håndtere dialogen med familierne.

"Vi har etableret en familiesupport med fire medarbejdere, som allerede nu rækker ud til forældre i fuldstændig samme situation, som dem vi måtte have fundet digitalt. Vi har haft flere hundrede familier igennem i meget små, korte, intensive familiebehandlingsforløb, og det vi oplever, det er, at der er ingen, der siger nej. Alle er taknemmelige for at få en hjælpende hånd - uden at der oprettes en social sag." (Børne- og kulturdirektør).

Etableringen af DAFO-enheden sikrede desuden interne dataspecialister og "et sted at gå hen og få hjælp" for de faglige centre i forvaltningen. Det er dog en velkendt problematik, at forskellige fagligheder kan have svært ved at forstå hinanden og at arbejde sammen. Denne udfordring er ikke mindst nærværende, når data- og digitaliseringsfaglighed er den ene part og fagpersoner med faglige tilgange er den anden part (Hoerl, 2020; Holten Møller, Shklovski og Hildebrandt, 2020). Derfor er det interessant, at Gladsaxe Kommune i forbindelse med projekt DTO anvendte en model, der i den konkrete kontekst anerkendes af de interviewede fagpersoner og direktører som velfungerende.

"Familieafdelingen har fået ideen ud fra et behov hos de udsatte børn og et fagligt ønske om at hjælpe. Driveren i projektet kommer fra styregruppen, der også tilføjer ressourcer. Og datamedarbejderne brænder også for det, fordi de kan se, det kan komme ud i virkeligheden bagefter." (Digitaliseringschef).

Det er respondenternes vurdering, at organiseringen af DAFO med kombinationen af faste medarbejdere og deltidsmedarbejdere fra fagcentrene sikrede en løbende vidensdeling og gensidig indsigt i fagområder. Medarbejderne i DAFO-enheden beskrives desuden som imødekommende og nysgerrige på fagcentrenes udfordringer. Projekt DTO var forankret i familieafdelingen og dermed socialfagligheden, hvilket medfører et vigtigt værdimæssigt fokusskift (Holten Møller, Shklovski og Hildebrandt, 2020) . Endelig havde projektet direktionens tydelige opbakning, hvilket kan ses på prioritering af ressourcer til projektet, direktionens formandskab i styregruppen samt opbakning under og efter mediekritikken. Direktionens deltagelse i styregruppen bidrog også til at etablere den fornødne indsigt i projektet og en velfungerende kobling i styringskæden mellem direktion og forvaltning. I et PVM-perspektiv kan det på baggrund af ovenstående argumenteres, at direktionen havde etableret den fornødne operationelle kapacitet til at gennemføre projekt DTO, som udgør det sidste led i Moores strategiske trekant. 


\section{Algoritmeaversion}

Et yderligere fund fra interviewene er, at flere respondenter fremhæver utryghed ved ordet "algoritmer" som en medvirkende årsag til udfaldet af casen.

”Ved et ord som algoritme kan jeg mærke på vore politikere, at det løber dem koldt ned ad ryggen, for hvad betyder det for hensynet til borgerne?" (By- og Miljødirektør).

Den menneskelige skepsis overfor algoritmer giver sig blandt andet udslag i, hvad der er beskrevet som "algoritmeaversion", hvor det i en række forsøg blev observeret, at forsøgsdeltagerne havde mindre tillid til forudsigelser fra algoritmer end mennesker, selv for de forsøgsdeltagere, som havde kendskab til, at algoritmens forudsigelser var mere præcise end menneskelige forudsigelser (Dietvorst, Simmons og Massey, 2015). Denne observation ligger i forlængelse af litteraturen om et "system-level bureacracy", hvor det anføres, at menneskelig skønsvurdering overtages af dataspecialister, som gennem opsætning af datamodeller i realiteten foretager myndighedens vurdering(Bovens og Zouridis, 2002). Som angivet i tidsforløbet var det hensigten i projekt DTO, at algoritmen alene skulle anvendes til identifikation og behandling af data, og ikke til hverken semieller fuldautomatisk sagsbehandling. Alligevel var bekymringer for algoritmernes påvirkning af sagsbehandlingen og en generel algoritmeaversion sandsynligvis medvirkende faktorer til mediekritikken og den aftagende politiske opbakning til projekt DTO.

\section{Opsummering}

På baggrund af tidsforløbet og analysen opsummerer figur 1 årsagerne til, at projekt DTO blev afbrudt.

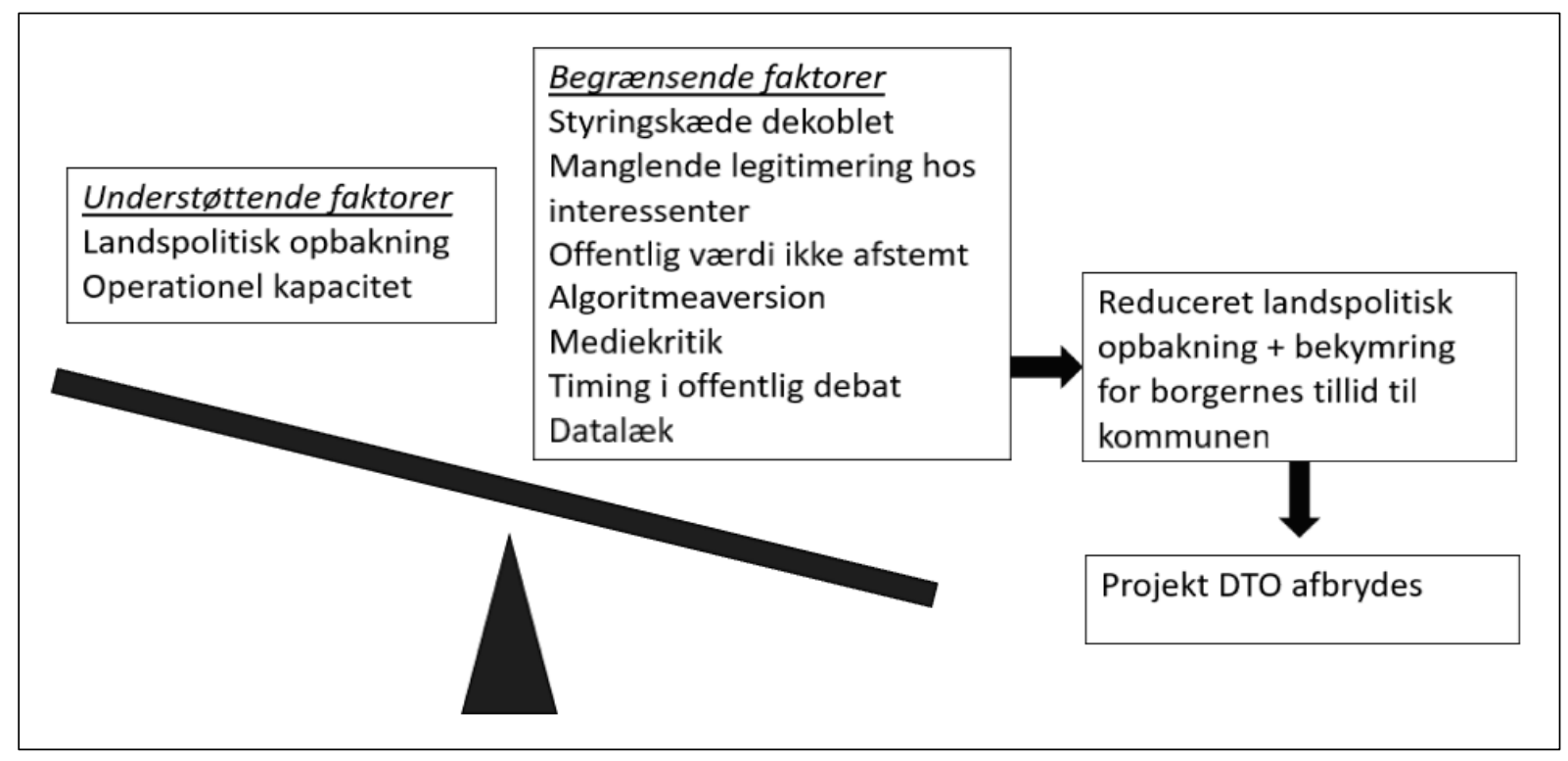

Figur 1. Årsager til at projekt DTO blev afbrudt 


\section{F. Konklusion}

Denne artikel indeholder en grundig beskrivelse af forløbet af projekt DTO i Gladsaxe Kommune og en analyse af årsager til projektets afbrydelse. Det kan konkluderes, at den operationelle kapacitet til projektet var etableret, og at der var landspolitisk opbakning. Selv om byrådet formelt havde godkendt projekt DTO, så var styringskæden mellem direktion/politikere og politikere/borgere reelt dekoblet, fordi politikerne ikke havde været tæt nok på projektet til at kunne forklare projektet for borgerne og i offentligheden. Projektet manglede derfor reel legitimering hos kommunalpolitikerne samt en bredere opbakning fra interessenter, borgere og medier. Forvaltningens opfattelse af offentlig værdi for de udsatte børn var ikke afstemt med offentlighedens bekymringer for overvågning, transparens, datalæk mv. Dette blev tydeligt, da Gladsaxe blev ramt af mediekritikken, der yderligere blev forstærket af algoritmeaversion og det tidsmæssige sammenfald med debatter om regeringens ghettoudspil og vedtagelsen af databeskyttelsesloven samt senere i forløbet en datalæk i kommunen. Disse forhold påvirkede negativt den landspolitiske opbakning til projekt DTO, og der opstod lokalt bekymring for borgernes tillid til kommunen. I sidste ende stod det klart for både direktion og politikere i Gladsaxe, at projektet måtte afbrydes for at bevare borgernes tillid til kommunen.

Casen har naturligvis sin egen kontekst og historik, som ikke nødvendigvis er til stede i andre kommuner. Alligevel kan der på baggrund af forløbet i Gladsaxe og med fokus på direktionens påvirkningsmuligheder identificeres følgende opmærksomhedspunkter for en kommunal direktion ved anvendelse af algoritmer i velfærdsopgaver: 1) Tæt involvering af politikere ved anvendelse af algoritmer i velfærdsopgaver. 2) Sikre politikernes forståelse af anvendelsen af algoritmer for at undgå dekobling af styringskæden. 3) Balancere offentlig værdi og skabe bred legitimitet og opbakning fra interessenter 4) Etablere operationel kapacitet i form af direktionens opbakning, ressourcer samt faglige og datamæssige kompetencer i tværfagligt samarbejde. 5) Sprogbevidsthed og algoritmeaversion som præmis. Disse opmærksomhedspunkter bidrager til litteraturen om anvendelse af algoritmer med et fokus på direktionens rolle samt med et empirisk eksempel på anvendeligheden af PVM.

\section{G. Diskussion}

Betydningen af opmærksomhedspunkterne vil variere med den konkrete kontekst, hvor Gladsaxe var kendetegnet ved politisk stabilitet samt relativt gode ressourcer og faglighed. Også temaet kan have betydning, hvor udsatte børn er et meget følsomt tema for anvendelse af algoritmer, der sætter dilemmaerne på spidsen. Det er således muligt, at andre opmærksomhedspunkter kunne være fremkommet ved casestudier af f.eks. statens algoritmemodel til anvendelse på kommunale jobcentre. Der er behov for studier af algoritmers anvendelse på forskellige velfærdsområder og 
gerne også mere teknologisk fokuserede studier af forskellige typer af algoritmer, samt hvordan disse anvendes i praksis i en kommune.

Denne artikel har fokuseret på direktionens perspektiv. Et relevant spørgsmål for videre studier vil være, i hvilken grad og hvordan topledelse af algoritmer adskiller sig fra topledelse af andre større omstillinger af den kommunale service? Umiddelbart kan det argumenteres, at alle fem opmærksomhedspunkter har stor lighed med "almindelig forandringsledelse" (f.eks. Kristiansen, 2019). Alligevel synes topledelse af projekter med algoritmer at have en ekstra dimension. Måske er kernen heri, at direktionen i de fleste kommuner har en lav forståelse af algoritmer og konsekvenserne heraf? Algoritmer kan opleves som en "sort boks", hvor udfaldet kan være meget svært at forudsige. Anvendelse af algoritmer i velfærdsopgaver kan derfor være forbundet med stor risiko.

I PVM-perspektivet er det netop en forventning, at direktionen går forrest og udviser mod til at udforske løsninger på komplekse samfundsudfordringer som socialt udsatte børn. Gladsaxecasen viser potentialet, men også risikoen ved, at direktionen tager teten i overvejelserne om anvendelse af algoritmer. Casen er en påmindelse om vigtigheden af ikke blot at have organisationen ombord, men også at have borgere og politikere med på rejsen. Det kræver mod at gå forrest, og dette mod udviste Gladsaxe Kommune med projekt DTO. Den daværende kommunaldirektør formulerer det næsten som en forpligtelse:

"Hvis sådan en kommune som os ikke gør sådan noget, hvem er det så, der skal gøre det?" (Daværende kommunaldirektør). 


\section{Referencer}

Aberbach, Joel D, Robert D Putnam og Bert A Rockman (1981). Bureaucrats and Politicians in Western Democracies Harvard University Press.

Andersen, Ayo Næsborg og Hanne Marie Motzfeldt (2019). Different Aspects of Transparency in Digital Government: The Danish Case. I (pp. 81-87,VIII-IX). Reading: Academic Conferences International Limited.

Andersen, Lotte Bøgh, Stefan Boye, Martin Bækgaard, Christian Bøtcher Jacobsen og Asbjørn Sonne Nørgaard (2019). Politisk og administrativ ledelse: Roller, relationer og personlighed i toppen af de danske kommuner. Djøf Forlag.

Andersen, Lotte Bøgh, Carsten Greve, Kurt Klaudi Klausen og Jacob Torfing (2020). Offentlige styringsparadigmer: Konkurrence og sameksistens. Djøf Forlag.

Andrews, Leighton (2019). Public administration, public leadership and the construction of public value in the age of the algorithm and 'big data'. Public Administration 97 (2): 296-310. https://doi.org/10.1111/padm.12534

Bach, Alexander, Jesper Svejgaard og Frederik Hjorth (2019). Maskinlæring som politologisk værktøj. Politica: Tidsskrift for Politisk Videnskab 51 (2).

Bertelsen, Tilde Marie og Morten Balle Hansen (2016). Kommunernes administrative lederskab anno 2016: Afrapportering fra en surveyundersøgelse til danske kommunale topchefer. Institut for Statskundskab, Aalborg Universitet.

Bjørn, Marie-Louise (2020). Good Will Hunting: Styringsstrategiske modsœtninger og ledelsesmaessige udfordringer i arbejdet med børnesager. Roskilde Universitet.

Blom-Hansen, Jens, Martin Baekgaard og Søren Serritzlew (2020). How bureaucrats shape political decisions: The role of policy information. Public Administration 1 (15).

https://doi.org/10.1111/padm.12709

Bovens, Mark og Stavros Zouridis (2002). From street-level to system-level bureaucracies: How information and communication technology is transforming administrative discretion and constitutional control. Public administration review 62 (2): 174-184. https://doi.org/10.1111/00333352.00168 
Bryson, John, Alessandro Sancino, John Benington og Eva Sørensen (2017). Towards a multi-actor theory of public value co-creation. Public Management Review 19 (5): 640-654. https://doi.org/10.1080/14719037.2016.1192164

Bullock, Justin B (2019). Artificial intelligence, discretion, and bureaucracy. The American Review of Public Administration 49 (7): 751-761. https://doi.org/10.1177/0275074019856123

Busch, Peter André, Helle Zinner Henriksen og Øystein Sæbø (2018). Opportunities and challenges of digitized discretionary practices: a public service worker perspective. Government Information Quarterly 35 (4): 547-556. https://doi.org/10.1016/j.giq.2018.09.003

Dietvorst, Berkeley J, Joseph P Simmons og Cade Massey (2015). Algorithm aversion: People erroneously avoid algorithms after seeing them err. Journal of Experimental Psychology: General 144 (1): 114. https://doi.org/10.1037/xge0000033

Dunleavy, Patrick, Helen Margetts, Simon Bastow og Jane Tinkler (2006). New public management is dead-long live digital-era governance. Journal of public administration research and theory 16 (3): 467-494. https://doi.org/10.1093/acprof:oso/9780199296194.001.0001

Flyvbjerg, Bent (2006). Five misunderstandings about case-study research. Qualitative inquiry 12 (2): 219-245. https://doi.org/10.1177/1077800405284363

Fontana, Andrea og James Frey (1994). The art of science. The handbook of qualitative research 361376.

Gillingham, Philip (2019). Can predictive algorithms assist decision-making in social work with children and families? Child abuse review 28 (2): 114-126. https://doi.org/10.1002/car.2547

Gjerding, Sebastian (2018). Kommune ville hjælpe udsatte børn - nu bliver den beskyldt for at gøre Danmark til DDR. Information. 7. marts 2018.

https://www.information.dk/indland/2018/03/kommune-hjaelpe-udsatte-boern-beskyldt-goeredanmark-ddr (3. november 2020).

Gladsaxe Kommune (2016). Strategi for tidlig opsporing - Familier der lykkes. https://gladsaxe.dk/Files//Files/Faelles-dokumenter/Planer-politikker-visioner/BKF/Strategi-forTidlig-indsats_v2.pdf (3. november 2020). 
Gladsaxe Kommune (2017). Ansøgning om konkrete forsøg i Frikommuneforsøg II Dataunderstøttet tidlig opsporing af udsatte børn. https://sim.dk/media/18887/forsoegsansoegninger-i-3-runde-frikommuneforsoeg-ii.pdf (28. December 2020).

Hjelmar, Ulf, Martin Bæksgaard Jakobsen, Amanda Thor Andersen og Iben Bolvig (2020). Helhedsindsats for udsatte familier: Virkninger og erfaringer med indsats i Gladsaxe Kommune 2016-2019. I: VIVE - Det Nationale Forsknings- og Analysecenter for Velfærd.

Hoerl, Roger W., Diego Kuonen, and Thomas C. Redman (2020). To succeed with data science, first build the "Bridge". MIT Sloan Management Review, 22 October 2020.

Holten Møller, Naja, Irina Shklovski og Thomas T Hildebrandt (2020). Shifting concepts of value: Designing algorithmic decision-support systems for public services. Proceedings of the 11th Nordic Conference on Human-Computer Interaction: Shaping Experiences, Shaping Society. https://doi.org/10.1145/3419249.3420149

Jensen, Tom og Mette Østergaard (2018). Den gode vilje fører direkte til overvågningssamfundet. Berlingske. 15. marts 2018. https://www.berlingske.dk/ledere/den-gode-vilje-foerer-direkte-tilovervaagningssamfundet (3. november 2020).

Jørgensen, Torben Beck og Barry Bozeman (2007). Public values: An inventory. Administration \& society 39 (3): 354-381. https://doi.org/10.1177/0095399707300703

KL (2019). På forkant med fremtidens velfærd, København. https://www.kl.dk/media/19309/paaforkant-med-fremtidens-velfaerd.pdf, (12. december 2020).

KL og Økonomi- og Indenrigsministeriet (2017). Det politiske arbejde i kommunalbestyrelse og udvalg. København. https://sim.dk/publikationer/2017/dec/det-politiske-arbejde-ikommunalbestyrelse-og-udvalg/ (30. november 2020).

Kristiansen, Mads Bøge (2019). Organisatorisk forandring: Et blik på litteraturen om forandringers indhold, kontekst og proces. Økonomi \& Politik 92 (2).

Lê Madsen, Carsten og Ulrik Kjær (2015). De sidste sande amatører: kommunalpolitikerne og deres rolle i det lokale demokrati Gyldendal. 
Lessel, Simon og Christina Houlind (2018). Kommune om dataovervågning af børnefamilier: Det er ikke et pointsystem. 8. marts 2018. https://www.altinget.dk/digital/artikel/gladsaxe-kommunedataovervaagning-skal-spotte-udsatte-boern-tidligere (3. november 2020).

Margetts, Helen og Patrick Dunleavy (2013). The second wave of digital-era governance: a quasiparadigm for government on the Web. Philosophical Transactions of the Royal Society A: Mathematical, Physical and Engineering Sciences 371 (1987).

https://doi.org/10.1098/rsta.2012.0382

Mchangama, Jacob og Hin-Yan Liu (2018). The Welfare State Is Committing Suicide by Artificial Intelligence. Foreignpolicy. com, 25. December 2018. https://foreignpolicy.com/2018/12/25/thewelfare-state-is-committing-suicide-by-artificial-intelligence/ (11. november 2020).

Mergel, Ines, R. Karl Rethemeyer og Kimberley Isett (2016). Big Data in Public Affairs. Public administration review 76 (6): 928-937. https://doi.org/10.1111/puar.12625

Miles, Matthew B og A Michael Huberman (1994). Qualitative data analysis: An expanded sourcebook. sage.

Mittelstadt, Brent Daniel, Patrick Allo, Mariarosaria Taddeo, Sandra Wachter og Luciano Floridi (2016). The ethics of algorithms: Mapping the debate. Big Data \& Society 3 (2): 2053951716679679. https://doi.org/10.1177/2053951716679679

Moore, Mark Harrison (1995). Creating public value: Strategic management in government. Harvard university press.

Moore, Mark og Sanjeev Khagram (2004). On creating public value: What business might learn from government about strategic management. Corporate Social Responsibility Initiative Working Paper 3.

Nielsen, Jeppe Agger, Kasper Elmholdt og Mette Strange Noesgaard (2020). Ledelse af digital transformation: Erfaringer fra et kommunalt digitaliseringsinitiativ. Samfundslederskab i Skandinavien 35 (6): 423-442. https://doi.org/10.22439/sis.v35i6.6110

Olsen, Henrik Palmer, Jacob Livingston Slosser, Thomas Troels Hildebrandt og Cornelius Wiesener (2019). What's in the Box? The Legal Requirement of Explainability in Computationally Aided Decision-Making in Public Administration. https://doi.org/10.2139/ssrn.3402974 
Olsen, Johan P. (1978). Politisk organisering: Organisasjonsteoretiske synspunkt på folkestyre og politisk ulikhet. Bergen: Universitetsforlaget.

Regeringen (2018). Et Danmark uden parallelsamfund - ingen ghettoer i 2030.

https://www.regeringen.dk/nyheder/2018/ghettoudspil/ (28. december 2020).

Regeringen (2019). I National strategi for kunstig intelligens. København.

https://www.regeringen.dk/media/6537/ai-strategi_web.pdf. (30. november 2020).

Rhodes, Rod AW og John Wanna (2007). The limits to public value, or rescuing responsible government from the platonic guardians. Australian Journal of Public Administration 66 (4): $406-$ 421. https://doi.org/10.1111/j.1467-8500.2007.00553.x

Ritzau Fokus (2018). Kommuner skal finde udsatte børn på baggrund af data. 27. februar 2018. https://apps-infomedia-dk.proxy3-bib.sdu.dk/mediearkiv/link?articles=e6a32e0c (3. november 2020).

Røhl, Ulrik (2020). Automatiseret sagsbehandling, big data og kunstig intelligens: Myndighedsrollen i en digital tidsalder. Digitech. 22. april 2020.

https://pro.ing.dk/digitech/artikel/automatiseret-sagsbehandling-big-data-og-kunstig-intelligensmyndighedsrollen-i-en (12. november 2020).

Smith-Udvalget, Bo (2015). Embedsmanden i det moderne folkestyre: Bo Smith-udvalgets rapport om samspillet mellem politikere og embedsmand DJØF's Forlag.

Sorgenfri Kjær, Jakob (2018a). Gladsaxe har lækket 20.000 borgeres fortrolige data. Politiken. 12. december 2018. https://apps-infomedia-dk.proxy3-bib.sdu.dk/mediearkiv/link?articles=e70204f0 (4. november 2020).

Sorgenfri Kjær, Jakob (2018b). Regeringen har lagt sin plan om overvågning af børnefamilier i skuffen. Politiken. 14. december 2018. https://apps-infomedia-dk.proxy3bib.sdu.dk/mediearkiv/link?articles=e702e844 (4. november 2020).

Sorgenfri Kjær, Jakob (2018c). Regeringen vil overvåge alle landets børnefamilier og uddele point. Politiken. 3. marts 2018. https://apps-infomedia-dk.proxy3bib.sdu.dk/mediearkiv/link?articles=e6a5ff67 (3. november 2020). 
Stoker, Gerry (2006). Public value management: a new narrative for networked governance? The American review of public administration 36 (1): 41-57.

https://doi.org/10.1177/0275074005282583

Svara, James H (1999). The shifting boundary between elected officials and city managers in large council-manager cities. Public Administration Review: 44-53. https://doi.org/10.2307/977478

Sweeney, Latanya (2000). Simple demographics often identify people uniquely. Health (San Francisco) 671 (2000): 1-34.

Sørensen, Per Byrge (2018). Brug af dataprofilering inden for sagsområdet, udsatte børn og unge. Nordisk administrativt tidsskrift online 95 (2). https://www.djoef-

forlag.dk/publications/nat/files/2018/2018_2/NAT_2_2018_3.pdf (30. november 2020).

Turkel, E og G Turkel (2016). Public value theory: Reconciling public interests, administrative autonomy and efficiency. Review Public Administration Management, an Open access journal 4 (2). https://doi.org/10.4172/2315-7844.1000189

Van Dalen, Arjen (2020). Synet på nyhedsalgoritmer. I Mediernes Forsknings- og Innovationscenter (red.): Syddansk Universitet. https://www.sdu.dk/-

/media/images/om_sdu/centre/journalistik/mfi/mfi+synet+paa+nyhedsalgoritmer.pdf (28. december 2020).

Weber, Max (1922 [Fivelsdal 1971]). Makt og byråkrati: essays om politikk og klasse, samfunnsforskning og verdier. Oslo: Gyldendal Norsk Forlag.

Wihlborg, Elin, Hannu Larsson og Karin Hedström (2016). " The Computer Says No!"--A Case Study on Automated Decision-Making in Public Authorities. 2016 49th Hawaii International Conference on System Sciences (HICSS). https://doi.org/10.1109/HICSS.2016.364

Winthereik, Brit Ross (2020). Brug af borgeres data: En problematisering af etik som fundament for digital velfærd. Tidsskrift for arbejdsliv 22. årgang nr. 3. https://doi.org/10.7146/tfa.v22i3.122827

Wirtz, Bernd W, Jan C Weyerer og Carolin Geyer (2019). Artificial intelligence and the public sector-applications and challenges. International Journal of Public Administration 42 (7): 596-615. https://doi.org/10.1080/01900692.2018.1498103 